\title{
SOSIALISASI PENDIDIKAN KARAKTER PADA LEMBAGA PEMBINAAN KHUSUS ANAK DI KUPANG
}

\author{
Silvester P. Taneo ${ }^{1}$, Benediktus Kasa ${ }^{2}$, Treesly Y Adoe $^{3)}$, Sarah Nurhabibah ${ }^{4)}$, Vera Rosalina \\ Bulu $^{5}$, Maxel Koro' \\ Program Studi Pendidikan Guru Sekolah Dasar, Fakultas Keguruan dan Ilmu Pendidikan, \\ Universitas Nusa Cendana, Indonesia ${ }^{1), 2), 3), 4,5), 6}$ \\ email: Veraros0451@gmail.com
}

\begin{tabular}{|l|l|l}
\hline Dikirim: 27-01-2021 & Direvisi: 22-03-2021 & Diterbitkan: 31-08-2021
\end{tabular}

\begin{abstract}
Abstrak
Tujuan dari kegiatan pengabdian kepada masyarakat ini yaitu Memberikan sosialisasi nilai - nilai karakter dan implementasi bagi anak - anak LPKA Kota Kupang dan memberikan motivasi kepada anak-anak di LPKA Kelas I Kupang untuk terus mengimplementasikan nilai - nilai karakter dalam rangka penguatan karakter dalam diri mereka. Kegiatan ini dilaksanakan secara daring pada dua tempat yaitu kampus B PGSD Universitas Nusa Cendana dan LPKA Kelas I Kota Kupang. Metode yang digunakan dalam penyampaian materi nilai - nilai karakter dan implementasinya yaitu metode ceramah, tanya jawab dan bermain peran. Kegiatan ini dilaksanakan selama tiga hari dimana pada hari pertama dan kedua, peserta diberikan materi mengenai nilai - nilai karakter dan implementasinya sedangkan pada hari ketiga peserta diberikan kesempatan untuk mengaplikasikan materi yang didapatkan pada hari pertama dan kedua dengan cara bermain peran. Berdasarkan penilaian pada hari pertama sampai dengan hari ketiga didaptkan hasil bahwa anak - anak binaan LPKA Kota Kupang mengalami peningkatan pemahaman mengenai nilai karakter dan implementasinya dalam kehidupan sehari-hari.
\end{abstract}

Kata Kunci: Sosialisasi, nilai karakter.

\begin{abstract}
The purpose of this community service activity is to provide socialization of character values and implementation for lpka children in Kupang city and to motivate children in LPKA Class I Kupang to continue to implement character values in order to strengthen the character in themselves. This activity was conducted online in two places, namely campus B PGSD Nusa Cendana University and LPKA Class I Kupang City. Methods used in the delivery of material values - character values and their implementation are methods of lectures, question and answer and role-playing. This activity was held for three days where on the first and second day, participants were given material about the values of character and implementation while on the third day participants were given the opportunity to apply the material obtained on the first and second day by role-playing. Based on the assessment on the first day to the third day, the results of lpka children in Kupang city experienced an increased understanding of the value of character and its implementation in daily life.
\end{abstract}

Keywords:: socialization, character value

\section{PENDAHULUAN}

Karakter merupakan sifat-sifat kejiwaan, akhlak atau budi pekerti yang membedakan seorang dari yang lain. Pembangunan karakter dan jati diri bangsa merupakan cita-cita luhur yang harus diwujudkan melaui penyelenggaraan pendidikan yang terarah dan berkelanjutan. Penanaman nilai-nilai akhlak, moral, dan budi pekerti seperti tertuang dalam Undang-undang 
Republik Indonesia No 20 Tahun 2003 tentang Sistem Pendidikan Nasional harus menjadi dasar pijakan utama dalam mendesain, melaksanakan, dan mengevaluasi sistem pendidikan nasional.

Pendidikan karakter menanamkan nilai - nilai karakter kepada seorang individu yang meliputi lmu pengetahuan, kesadaran, kemauan dan tindakan untuk dapat melaksanakan nilainilai tersebut baik terhadap Tuhan YME, dirinya sendiri, orang lain, lingkungannya maupun bangsa dan negaranya. Seseorang memiliki karakter yang baik jika memiliki nilai - nilai yang ada hubungannya dengan Tuhan yang Maha Esa, sesama manusia, diri sendiri dan lingkungan.

Pendidikan karakter berperan sebagai kendaraan yang membawa nilai - nilai baik untuk diterapkan dalam kehidupan pribadi dan bermasyarakat. Selain itu, nilai - nilai karakter dapat menjadikan individu untuk memperkuat pegangan akan nilai - nilai karakter sehingga dapat menangkal berbagai bentuk pelanggaran berkaitan dengan karakter. Hal ini juga sejalan dengan pendapat (Wahidin 2017) yang menyatakan bahwa pendidikan karakter dapat membentuk seseorang untuk memiliki akhlak mulia.

Faktanya kejadian yang berkaitan dengan pelanggaran karakter muncul di masyarakat akhir - akhir ini cukup mengakhawatirkan misalnya tindak kekerasan, pelanggaram HAM, indisipliner, anarkisme, korupsi, ketidakjujuran, pecurian, seks bebas dan sebagainya. Salah satu solusi untuk mengatasi pelanggaran tersebut yaitu pelaksanaan pendidikan karakter yang secara terus menerus dalam masyarakat diantaranya melalui sosialisasi nilai - nilai karakter. Hal ini sejalan dengan pendapat (Suyanta 2013; Waluyo 2018) yang menyatakan bahwa akhir - akhir ini terjadi krisis nilai karakter yang terjadi hamper pada semua elemen masyarakat mulai dari orang dewasa sampai anak - anak.

Lembaga pembinaan kelas anak (LPKA) Kota Kupang merupakan tempat membina anak-anak yang melakukan kasus kriminal di Kota Kupang. Jumlah anak - anak yang terkena kasus kriminal sampai tahun 2020 sebanyak 29 orang. Pelanggaran yang dilakukan di dominasi oleh kasus percabulan/ pemerkosaan anak di bawah umur, selebihnya yaitu kasus pencurian, kekerasan/ perkelahian antar remaja dan sebagainya. Oleh sebab itu salah satu kebutuhan oleh anak - anak binaan pada LPKA Kota Kupang yaitu penguatan nilai - nilai karakter yang secara konsisten dilakukan. Salah satu cara yang dapat dilakukan yaitu sosialisasi nilai-nilai karakter dalam rangka penguatan nilai - nilai karakter anak. Hal ini sejalan dengan pendapat (Ekowati, Nggonggoek, and Utomo 2019; Zairina and Mulyanto 2016) yang menyatakan bahwa adanya sosialisasi nilai - nilai karakter anak akan dapat memperbaiki mental anak.

Adapun tujuan dari kegiatan ini yaitu memberikan sosialisasi nilai - nilai karakter dan implementasinya serta memberikan motivasi kepada anak - anak di LPKA kelas I kupang untuk terus mengimplementasikan nilai - nilai karakter dalam rangka penguatan karakter dalam diri mereka. Sehingga target yang akan dicapai dalam kegiatan pengandian ini yaitu anak - anak binaan di LPKA kelas I kupang dapat memahami tentang nilai - nilai karakter dan termotivasi untuk mengimplementasinya dalam kehidupan sehari - hari, 


\section{METODE}

Kegiatan pengabdian masyarakat ini dilakukan secara daring, dimana tempat pelaksanaan di dua tempat yaitu tim pengabdian berada di kampus B PGSD Universitas Nusa Cendana sedangkan Peserta yaitu anak - anak binaan yang berjumlah 20 orang berada di LPKA Kelas I Kota Kupang. Tim Pengabdian tidak diijinkan masuk di lokasi kegiatan ini sebab terjadi lonjakan kasus covid -19 pada bulan tersebut sehingga TIM pengabdian dan Peserta dipertemukan secara tatap maya. Kegiatan ini berlangsung selama 3 hari, dimana digunakan 2 jam dalam hari tersebut. Sehingga total waktu yang digunakan untuk kegiatan pengabdian ini kurang lebih 6 jam. Metode yang digunakan dalan kegiatan PkM ini yaitu metode ceramah, tanya jawab dan bermain peran. Kegiatan pada hari selasa, 14 september 2020 dan rabu, 15 september 2020 yaitu sosialisasi nilai - nilai karakter dan implementasinya dalam kehidupan sehari - hari. Selanjutnya pada hari kamis, 16 September 2020 diberikan kesempatan bagi anak - anak LPKA untuk bermain peran berkaitan dengan nilai - nilai karakter dan implementasinya dalam kehidupan sehari - hari.

\section{HASIL DAN PEMBAHASAN}

Kegiatan pengabdian Masyarakat ini bertujuan untuk memberikan pengetahuan dan motivasi mengenai nilai - nilai karakter dan implementasinya dalam kehidupan sehari - hari. Kegiatan pengabdian masyarakat berjalan sesuai dengan jadwal yaitu dimulai pada hari senin, 22 Juni 2020 tim pelaksana pengabdian masyarakat melakukan survei pada LPKA anak kota kupang, mengenai masalah - masalah yang sering terjadi dalam LPKA ini. Berdasarkan hasil survei tersebut, didapatkan bahwa anak - anak di LPKA kurang memegang nilai - nilai karakter yang baik sehingga mereka terjerumus dalam kasus - kasus yang membuat mereka harus di bina di LPKA Kota Kupang. Pembinaan berkaitan dengan karakter di LPKA sering dilakukan baik oleh pegawai di LPKA atau dari lembaga - lembaga lainnya di Kota Kupang. Selanjutnya, ditemukan bahwa anak - anak di LPKA Kota Kupang perlu dibina terus menerus sehingga terjadi penguatan nilai - nilai karakter dalam diri anak - anak di LPKA tersebut. Berdasarkan temuan tersebut, maka tim pengadian menyepakati waktu pengabdian masyarakat dalam bentuk sosialisasi nilai - nilai karakter dan implementasinya.

Kegiatan sosialisasi nilai - nilai karakter berlangsung pada Selasa, 14 September 2020 sampai 15 September 2020 pukul 10.00 - 12.00. Pihak LPKA mengijinkan untuk melakukan sosialisasi secara virtual mengingat kasus Covid - 19 di Kota Kupang semakin meningkat sampai dengan September 2020. Kegiatan evaluasi pada hari kamis, 16 September 2020 di berikan dengan cara memberikan kesempatan bagi anak - anak LPKA untuk bermain peran berkaitan dengan nilai - nilai karakter, Pembicara dalam sosialisasi ini yaitu Dr. Silvester Taneo, M.Si., Dr. Benediktus Kasa, M,Si. Dan Sarah Nurhabibah, M.Pd.

Peserta yang mengikuti sebanyak 20 orang dari 29 orang anak - anak di LPKA. Hal ini dikarenakan pihak LPKA tidak mengizinkan banyak peserta berkumpul dalam satu ruangan. Hasil yang diperoleh anak - anak LPKA Kota Kupang mendapatkan peningkatan pengetahuan mengenai nilai - nilai karakter dan implementasinya dalam rangka penguatan karakter dalam diri masing - masing. Hal ini terlihat dari kegiatan bermain peran yang dilakukan di hari 
terakhir, anak - anak binaan LPKA kupang dapat memainkan peran dengan baik dan menjelaskan ulang setiap materi dalam percakapan yang dilakukan.

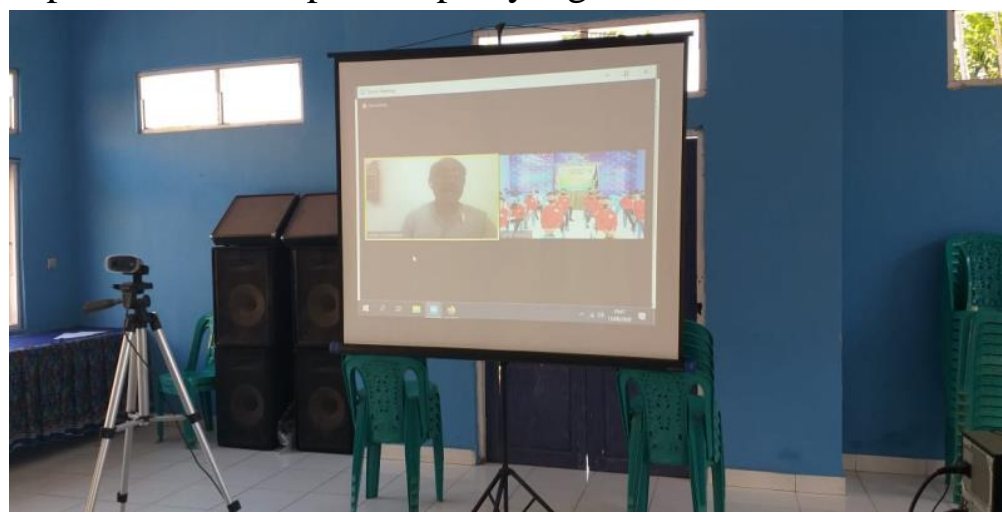

Gambar 1. Pemateri Sedang Memberikan Materi Mangenai Nilai - Nilai

Karakter

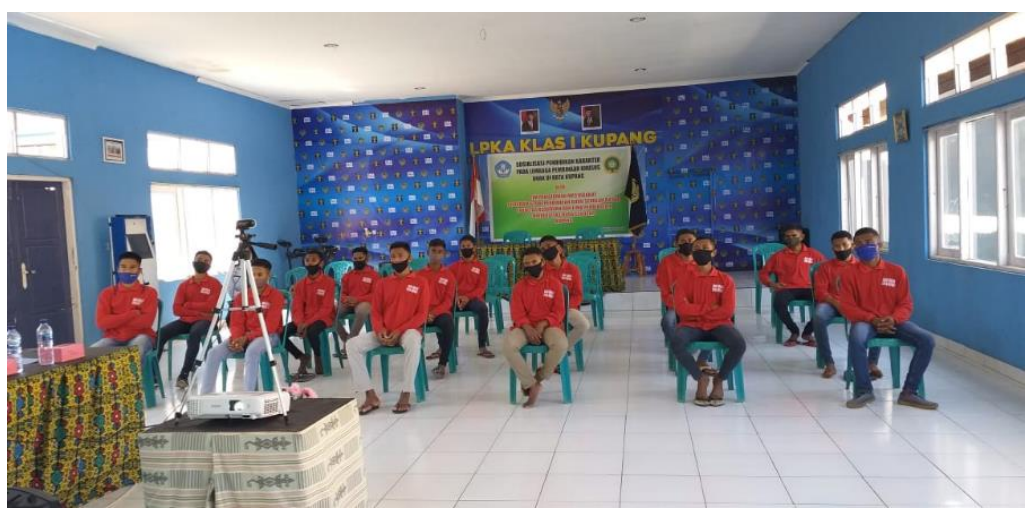

Gambar 2. Anak - Anak LPKA Mengikuti Materi Mangenai Nilai - Nilai Karakter

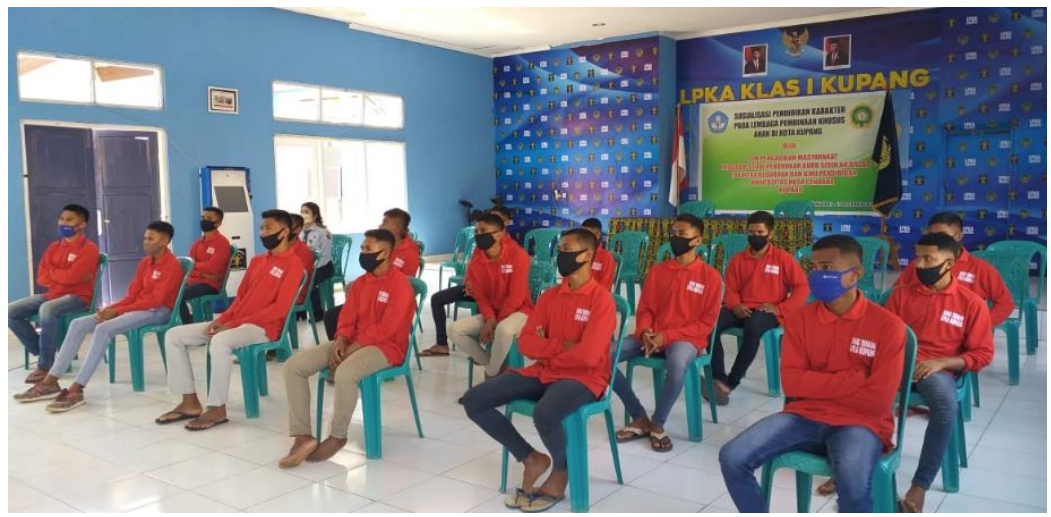

Gambar 3. Anak - Anak LPKA Mengikuti Materi Mangenai Nilai - Nilai Karakter

\section{SIMPULAN}

Kegiatan pengabdian kepada masyarakat berupa sosialisasi nilai - nilai karakter dan implementasinya dapat berjalan dengan baik dan hasil yang didapatkan yaitu peningkatan pemahaman anak - anak binaan mengenai materi nilai - nilai karakter dan implementasinya 
dalam kehidupan sehari - hari. Adapun manfaat dari kegiatan ini yaitu mengembangkan dan mereview pengetahuan mengenai nilai - nilai karakter dan mengimplementasikan pengetahuan tersebut dalam kegiatan sosialisasi ini. Selanjutnya manfaat yang dapat dirasakan oleh anak anak LPKA yaitu peningkatan pemahaman mengenai nilai karakter dan implementasinya. Adapun rekomendasi bagi pihak LPKA yaitu kegiatan ini perlu dilakukan secara rutin agar nilai - nilai karakter terus tertanam dalam diri anak - anak binaan LPKA Kelas I Kota Kupang.

\section{UCAPAN TERIMA KASIH}

Tim Pengabdian masyarakat mengucapkan terimakasih kepada pihak LPKA kelas I Kupang yang telah memberikan kesempatan kepada Tim untuk melakukan pengabdian kepada masyarakat berupa sosialisasi nilai - nilai karakter dan implementasinya. Selanjutnya, tim pengabdian juga mengucapkan terimakasih kepada FKIP Universitas Nusa Cendana yang telah memberikan bantuan dana untuk pelaksanaan kegiatan ini.

\section{DAFTAR PUSTAKA}

Ekowati, Uni, Wellem Nggonggoek, and Susilo Setyo Utomo. 2019. "Sosialisasi Pendidikan Karakter Berbasis Budaya Pada Anak-Anak Dengan Media Video." SELAPARANG Jurnal Pengabdian Masyarakat Berkemajuan 2(2):19. doi: 10.31764/jpmb.v2i2.881.

Suyanta, Sri. 2013. "Membangun Pendidikan Karakter Dalam Masyarakat." Jurnal Ilmiah Islam Futura 13(1):1. doi: 10.22373/jiif.v13i1.568.

Wahidin, Unang. 2017. "Pendidikan Karakter Bagi Remaja." Edukasi Islami: Jurnal Pendidikan Islam 2(03). doi: 10.30868/ei.v2i03.29.

Waluyo, Agus. 2018. "Sosialisasi Pendidikan Nilai Dan Karakter Di Masyarakat.” Jurnal ElHamra 3(3):75-80.

Zairina, Dahlia, and M. Ridhah Taqwa Mulyanto. 2016. "Sosialisasi Nilai - Nilai Pendidikan Karakter Bangsa” Jurnal Empirika,1 (1): 27 - 44. 